\section{Prevalence of cervical intraepithelial neoplasia and invasive carcinoma based on cytological screening in the region of Campinas, São Paulo, Brazil}

\author{
Prevalência da neoplasia intra-epitelial \\ cervical e do carcinoma invasivo com base \\ no rastreamento citológico na região \\ de Campinas, São Paulo, Brasil
}

Maria Gabriela L. d'Ottaviano-Morelli 1

Luiz Zeferino 1,2

José Guilherme Cecatti 1,2

Débora Raquel Terrabuio 1

Edson Zangiacomi Martinez 2

\footnotetext{
1 Departamento de

Tocoginecologia, Faculdade

de Ciências Médicas,

Universidade Estadual de

Campinas, Campinas, Brasil.

2 Centro de Atenção Integral

à Saúde da Mulher,

Universidade Estadual de

Campinas, Campinas, Brasil.

Correspondence

Luiz Zeferino

Departamento

de Tocoginecologia,

Faculdade de Ciências

Médicas, Universidade

Estadual de Campinas.

Rua Alexander Fleming 101,

Campinas, $S P$

13083-970, Brasil.

zeferino@caism.unicamp.br
}

\begin{abstract}
This study aimed to estimate and analyze the prevalence of cervical intraepithelial neoplasia (CIN) and invasive cervical carcinoma based on cytological diagnosis. The study included 120,635 women undergoing cytological exams in public health services in the region of Campinas, São Paulo State, Brazil, between September 1998 and March 1999. Prevalence rates per 100,000 women were: 354 for CIN I; 255 for CIN II; 141 for CIN III; and 24 for invasive carcinoma. As age increased, prevalence rates and prevalence ratios decreased for CIN grades I and II and increased for CIN III until the 50-54 age group, decreasing thereafter The prevalence rate of invasive carcinoma increased with age. The prevalence pattern of CIN II was distinct from that of CIN III, but similar to that of CIN I. This would not have been observed if the Bethesda System had been used for cytological diagnosis. Mean age at time of CIN II diagnosis was about 10 years less than for CIN III diagnosis. Therefore, a high-grade lesion diagnosed in a young woman according to the Bethesda System would probably be a CIN II, whereas in an older woman it would probably be a CIN III.
\end{abstract}

Cervical Intraepithelial Neoplasia; Uterine Neoplasms; Prevalence

\section{Introduction}

Cervical cancer, with its high incidence, is an important cause of death in developing countries, where socioeconomic conditions are precarious and screening programs do not adequately achieve their goals 1 .

Cervical cancer screening in Campinas began in 1968. Since the beginning, the screening model established that Pap smear sample collection would be decentralized and that the $\mathrm{Cy}$ tology Laboratory at the State University in Campinas (UNICAMP) would be centralized. Gradually, screening extended to other municipal districts of the region, UNICAMP being the main reference center for assisting women from community health centers who had been identified as having abnormal Pap test results 2 .

Until 1998 there were no data on the prevalence rate of cervical intraepithelial neoplasia (CIN) among the population in the region of Campinas. The data available referred to the total number of exams performed in regional cytological laboratories, which only discriminated between positive and negative results. Therefore, information on age-specific prevalence was not available. In addition, until that year no population data were available on agespecific prevalence rates of cervical intraepithelial lesions in other regions of Brazil.

This study thus aimed to estimate the prevalence rate of cervical intraepithelial lesions and 
invasive cervical carcinoma based on cytological diagnosis, as well as to analyze trends according to age at time of diagnosis.

\section{Subjects and methods}

This cross-sectional study was aimed at a female population of public health system clients from 64 cities situated in the region of Campinas, who were submitted to a Pap test for cervical cancer screening. Campinas, a city in the State of São Paulo with a population of approximately one million, is the hub of regional economic and university activities. The region screened for cervical cancer has approximately three and a half million inhabitants. It is estimated that almost $60 \%$ of the region's population depends on the public health system, mostly represented by the lower socioeconomic population. The samples were collected in community health units under local supervision. Current health policy suggests screening women between ages 25 and 60 every three years, after two normal tests performed at one-year intervals. Many of these municipal districts now have their own colposcopy clinics.

The study population included 131,207 women receiving Pap smears for cervical cancer screening in public health services between September 1998 and March 1999, whose slides had been processed and examined at the UNICAMP Cytology Laboratory. This Laboratory is responsible for approximately $70 \%$ of the cytological exams performed by the public health system in the Campinas region.

The study excluded pregnant women $(5,278)$, those submitted to hysterectomy $(3,472)$, and those of unknown or inconsistent ages $(3,232)$. The same woman could present more than one exclusion criterion. When a woman underwent repeat tests during the study period, only the result of the first test was considered. Thus a total of 120,635 women met the inclusion criteria and were admitted to the study.

The classification proposed by Richart 3 for cervical intraepithelial neoplasia was used in this study because the goal was to study CIN grades II and III separately. Samples were collected with an Ayre spatula and cytobrush.

Data were collected from the Pap test form adopted by the Cytology Laboratory and available in all public health services, designed for reading on optical mark readers. This form was introduced in August 1998 after a development period and performance test in two community outpatient clinics. The first month that this form was used was dedicated to identifying system errors and difficulties met by the community health centers. During this period a computer-based system was developed to detect data incompatibility or inconsistencies during the form's optical reading. Forms presenting incompatibilities and inconsistencies were rejected. The system could accept only one cytological diagnosis for each cell type, either squamous or glandular, in addition to the diagnosis of "cytopathic effect suggestive of HPV".

Prevalence rates for each cytological diagnosis and the prevalence ratio (PR) with $95 \%$ confidence interval (CI) were calculated according to age at diagnosis. The reference group for CIN PR was women aged 19 or younger and for invasive carcinoma PR was women aged 20 to 24 , since no diagnosis of this lesion was observed in the group aged 19 or younger. Linear PR variations with increasing age group were tested using the Cochran-Armitage Trend Test 4 .

\section{Results}

Some $20 \%$ of the women were under 25 years of age and two-thirds were 39 or younger, while only $5.4 \%$ were over 59 . Approximately $50 \%$ of the women undergoing a Pap smear for the first time were under 25 (Figure 1). Almost onesixth $(19,635)$ of the women were receiving their first Pap smear, and $40 \%, 19.9 \%, 8.7 \%$, and $6.2 \%$ were repeating the test, after one-, two-, three-, and more than five-year intervals, respectively (data not shown).

Mean ages at cytological diagnoses were 28.0, 29.3, 38.1, and 51.7 years for CIN grades I, II, III, and invasive carcinoma, respectively. For all diagnoses, the 50th age percentile varied from one to three years below the mean age (Table 1).

The overall prevalence rate of intraepithelial and invasive lesions was 774 per 100,000 women. Prevalence rates were 354 per 100,000 women for CIN I, 255 for CIN II, 141 for CIN III, and 24 for invasive carcinoma (Table 2).

According to the Cochran-Armitage Trend Test, prevalence ratios for CIN grades I and II decreased significantly as age increased. Conversely, prevalence ratios for CIN III and invasive carcinoma presented an upward trend as age increased, despite a slight decrease in CIN III above 50-54 years. Prevalence ratios for CIN I were less than 0.10 for the 50-54 age group or older. The highest CIN III prevalence ratio was in the 50-54-year group (Table 3). 


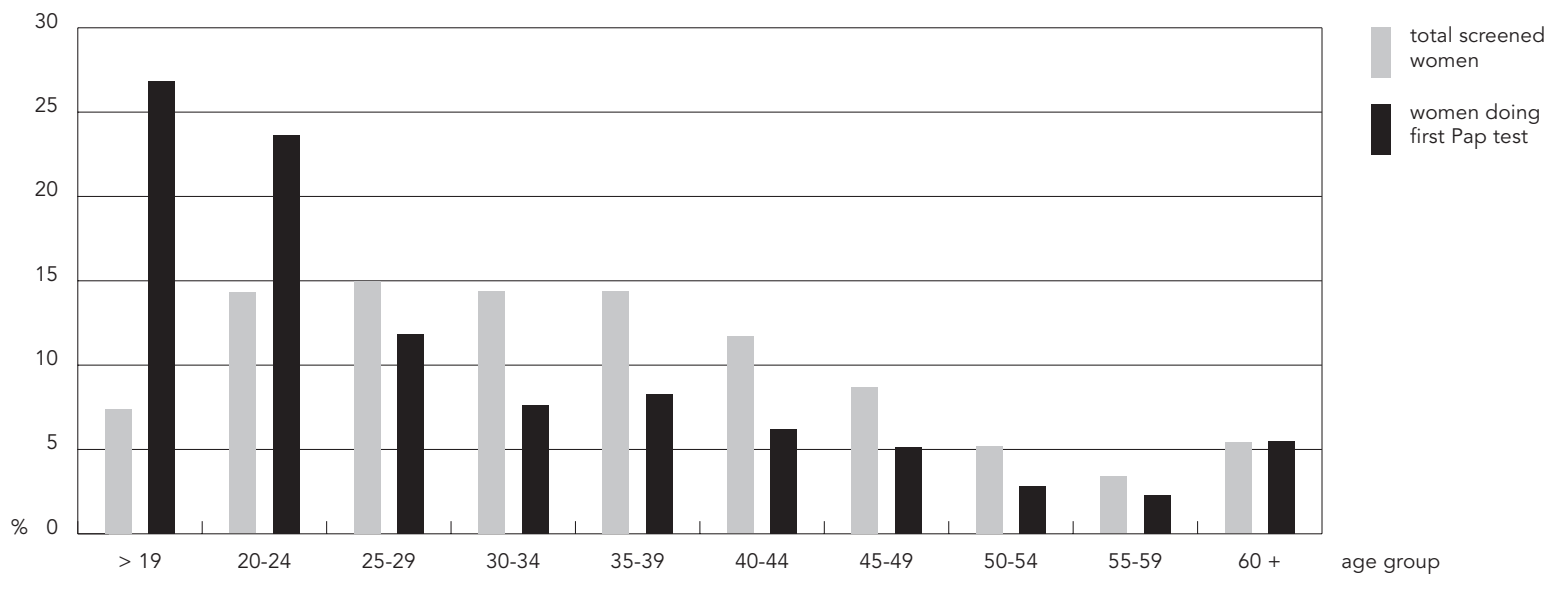

Mean and percentile of age (years) according to cytological diagnosis.

\begin{tabular}{|c|c|c|c|c|c|}
\hline & 25th percentile & 50th percentile & 75th percentile & Mean (SD) & Total women \\
\hline CIN I & 20 & 25 & 34 & $28.0(9.7)$ & 427 \\
\hline CIN II & 22 & 27 & 35 & $29.3(9.5)$ & 308 \\
\hline CIN III & 28 & 37 & 46 & $38.1(12.1)$ & 170 \\
\hline Invasive carcinoma & 43 & 49 & 59 & $51.7(14.7)$ & 29 \\
\hline Total women & 26 & 34 & 43 & $35.7(12.8)$ & 120,635 \\
\hline
\end{tabular}

$\mathrm{CIN}=$ cervical intraepithelial neoplasia.

\section{Discussion}

Data from 1988 for the State of São Paulo, Brazil, on prevalence rates of cervical lesions showed 860 CIN I per 100,000 cytological tests, 270 CIN II per 100,000, 160 CIN III per 100,000, and 70 invasive carcinomas per 100,000 tests. This database registered 170,754 tests in 120,604 women. Some women thus had repeat tests. Furthermore, there was no information as to whether tests from the cervical pathology outpatient clinic had been excluded. These tests could bias estimates of the prevalence rates due to the higher number of abnormal cytological tests in this group of women. There is also no information on the variability of CIN prevalence rates according to age 5 .
Brazilian data from the cervical cancer screening information system of the Health Ministry (SISCOLO) for the year 2000 showed $2,262,383$, and 54 per 100,000 Pap tests with cytological diagnoses of low-grade squamous intraepithelial lesion (LSIL), high-grade squamous intraepithelial lesion (HSIL), and invasive cervical cancer, respectively 6 . The LSIL diagnosis of the Bethesda System includes the Richart CIN I diagnosis 3 plus the HPV cytological diagnosis, and therefore there is no equivalent diagnosis in our study. The HSIL cytological diagnosis of the Bethesda System is equivalent to the combined diagnoses of CIN grades II and III 7. Thus, the HSIL prevalence rate in the Brazilian data could be con- 
Prevalence (per 100,000 women) of CIN and invasive carcinoma by age-group.

\begin{tabular}{|c|c|c|c|c|c|c|c|c|c|}
\hline \multirow[t]{2}{*}{ Age group } & \multicolumn{2}{|c|}{ CIN I } & \multicolumn{2}{|c|}{ CIN II } & \multicolumn{2}{|c|}{ CIN III } & \multicolumn{2}{|c|}{ Invasive carcinoma } & \multirow[t]{2}{*}{ Total women } \\
\hline & $n$ & Prevalence & $\mathrm{n}$ & Prevalence & $\mathrm{n}$ & Prevalence & $n$ & Prevalence & \\
\hline$\leq 19$ & 86 & 958 & 46 & 512 & 3 & 33 & 0 & 0 & 8,977 \\
\hline $20-24$ & 113 & 653 & 67 & 387 & 18 & 104 & 1 & 7 & 17,295 \\
\hline $25-29$ & 63 & 347 & 65 & 358 & 26 & 143 & 1 & 6 & 18,147 \\
\hline $30-34$ & 61 & 352 & 50 & 289 & 25 & 144 & 2 & 12 & 17,326 \\
\hline $35-39$ & 50 & 288 & 34 & 196 & 29 & 167 & 0 & 0 & 17,377 \\
\hline $40-44$ & 22 & 156 & 17 & 121 & 18 & 128 & 6 & 43 & 14,100 \\
\hline $45-49$ & 22 & 210 & 17 & 163 & 21 & 201 & 5 & 48 & 10,459 \\
\hline $50-54$ & 4 & 63 & 9 & 143 & 16 & 254 & 4 & 63 & 6,309 \\
\hline $55-59$ & 4 & 97 & 3 & 72 & 6 & 145 & 3 & 72 & 4,145 \\
\hline$\geq 60$ & 2 & 31 & 0 & 0 & 8 & 123 & 7 & 108 & 6,500 \\
\hline Total women & 427 & 354 & 308 & 255 & 170 & 141 & 29 & 24 & 120,635 \\
\hline
\end{tabular}

$\mathrm{CIN}=$ cervical intraepithelial neoplasia.

Table 3

Prevalence ratio of $\mathrm{CIN}$ and invasive carcinoma by age group.

\begin{tabular}{|c|c|c|c|c|c|c|c|c|}
\hline \multirow[t]{2}{*}{ Age group } & \multicolumn{2}{|c|}{ CIN I } & \multicolumn{2}{|c|}{ CIN II } & \multicolumn{2}{|c|}{ CIN III } & \multicolumn{2}{|c|}{ Invasive carcinoma } \\
\hline & PR & $95 \% \mathrm{Cl}$ & PR & $95 \% \mathrm{Cl}$ & PR & $95 \% \mathrm{Cl}$ & PR & $95 \% \mathrm{Cl}$ \\
\hline$<19$ & 1.00 & - & 1.00 & - & 1.00 & - & - & - \\
\hline $20-24$ & 0.68 & $0.52-0.90$ & 0.75 & $0.52-1.10$ & 3.11 & $0.92-10.57$ & 1.00 & - \\
\hline $25-29$ & 0.36 & $0.26-0.50$ & 0.69 & $0.48-1.02$ & 4.28 & $1.30-14.16$ & 0.95 & $0.02-36.40$ \\
\hline $30-34$ & 0.36 & $0.26-0.51$ & 0.56 & $0.38-0.84$ & 4.31 & $1.30-14.30$ & 1.99 & $0.09-46.80$ \\
\hline $35-39$ & 0.30 & $0.21-0.43$ & 0.38 & $0.25-0.59$ & 4.99 & $1.52-16.39$ & - & - \\
\hline $40-44$ & 0.16 & $0.10-0.26$ & 0.23 & $0.13-0.41$ & 3.82 & $1.13-12.96$ & 7.35 & $0.46-118.87$ \\
\hline $45-49$ & 0.21 & $0.14-0.35$ & 0.31 & $0.18-0.55$ & 6.00 & $1.79-20.14$ & 8.26 & $0.49-138.92$ \\
\hline $50-54$ & 0.06 & $0.02-0.18$ & 0.27 & $0.14-0.57$ & 7.58 & $2.21-26.03$ & 10.96 & $0.62-195.26$ \\
\hline $55-59$ & 0.10 & $0.04-0.27$ & 0.14 & $0.04-0.45$ & 4.3 & $1.08-17.31$ & 12.51 & $0.64-244.96$ \\
\hline$>60$ & 0.03 & $0.01-0.13$ & - & - & 3.68 & $0.98-13.88$ & 18.62 & $1.19-292.35$ \\
\hline \multirow[t]{2}{*}{ CATT } & \multicolumn{2}{|c|}{-12.52} & \multicolumn{2}{|c|}{-8.81} & \multicolumn{2}{|c|}{2.61} & \multicolumn{2}{|c|}{5.88} \\
\hline & \multicolumn{2}{|c|}{$p<0.001$} & \multicolumn{2}{|c|}{$p<0.001$} & \multicolumn{2}{|c|}{$p<0.01$} & \multicolumn{2}{|c|}{$p<0.001$} \\
\hline
\end{tabular}

PR = prevalence ratio; $\mathrm{CIN}=$ cervical intraepithelial neoplasia; $\mathrm{Cl}=$ confidence interval; CATT = Cochran-Armitage Trend Test 4 .

There were no invasive carcinoma cases among women in the "19 years and under" and "35-39 year" age groups.

sidered similar to the CIN II plus CIN III prevalence rates observed in this study, i.e., 396 per 100,000 .

SISCOLO data from the State of Paraná, Brazil, from January to October 2002 showed prevalence rates for CIN grades I, II, and III of 262,249 , and 124 per 100,000 women, respectively 8 , and the data are similar to those obtained in the current study. The SISCOLO reports consulted had no information available on age-specific prevalence rates.
Other studies have shown prevalence rates for overall abnormal cytological diagnoses from screening programs in different countries. In two studies in Holland, rates of abnormal Pap tests, including all abnormal diagnoses, were 540 per 100,000 9 and 800 per 100,000 10. In Thailand, 1,250 abnormal cytological diagnoses per 100,000 women 11 and in Chile 1,430 abnormal cytological diagnoses per 100,000 women were observed 12 . More recently, a study in a rural Costa Rican population showed a 
prevalence rate of abnormal Pap tests of $2.2 \%$ LSIL and 1.5\% HSIL 13. An American study included 628,085 women, almost half of whom from ethnic minority groups. Prevalence rates of abnormal results were $3.2 \%, 3.0 \%$, and $2.7 \%$, respectively, among blacks, whites, and Hispanics, according to the Bethesda System 14.

Research using the Bethesda System has shown a higher prevalence rate than the current study and others. In fact, the Bethesda System includes atypical squamous cells of undetermined significance, atypical glandular cells of undetermined significance, and HPV cytological diagnoses, which increase the overall prevalence of abnormal results 7 . These diagnostic classes do not exist in the Richart system ${ }^{3}$.

At any rate, prevalence rates of cervical intraepithelial lesions, regardless of classification, present widely varied values. This may be attributed to cervical cancer screening, diverse collection techniques, quality of samples, and especially differences in diagnostic criteria. In addition, all prevalence rates mentioned are crude rates that do not consider the difference in age distribution for each population.

The decreasing range of prevalence rates for CIN grades I and II according to age observed in this study was wider than the increasing range in prevalence rates for CIN III or invasive carcinoma. Therefore, the decrease in the prevalence rates of CIN grades I and II could be due mainly to cytological screening or spontaneous regression of these lesions, rather than progression to more severe diagnoses 15 . The decreasing trend of prevalence rates for CIN grades I and II is consistent with a higher HPV infection rate among younger women and spontaneous cure with follow-up time 13,16,17.

On the other hand, CIN III is associated with persistent oncogenic HPV infection 18,19. Compared to CIN grades I and II, CIN III has a lower percentage of spontaneous regression and a higher percentage of progression to invasive carcinoma 15. Furthermore, the mean estimated duration of CIN III is approximately 10 years, meaning that there is a cumulative annual incidence which influences the prevalence rates 20 .
CIN III prevalence peaked in the 55 to 59 age group and decreased in the older age groups, and this trend could be due to spontaneous regression or progression to invasive carcinoma in this age group 15. Treatment of CIN III could also lead to a decrease in its prevalence rate due to cervical cancer screening. Data from Sweden, Canada, United States, and Great Britain presented a peak prevalence for in situ carcinoma between ages 35 and 40, thus earlier than the peak found in Campinas 21 . However, these countries had established their cervical cancer screening programs earlier and for several decades in a more systematic way. As a consequence, the prevalence rate peaked in younger women and its decline was earlier and more abrupt, possibly due to earlier detection and efficient treatment of these lesions.

As previously mentioned, the Bethesda System considers the combined diagnoses of CIN grades II e III as HSIL. But the prevalence rate of CIN II according to age is similar to that of CIN I and different from that of CIN III, which would not have been observed if the Bethesda classification had been used. Also, mean age at the time CIN grades I and II were diagnosed was similar and about 10 years younger than the mean age in which CIN III was diagnosed.

Therefore, an HSIL diagnosed in a young woman would probably be a CIN II. If it were diagnosed in a woman over 50 , it would probably be a CIN III. Results observed by Herrero et al. 13 in his population-based study in a rural Costa Rican population emphasize this possibility, since the prevalence rate of HSIL presented two peaks, the first around age 30, possibly due to CIN II, and the second around age 65 , possibly due to CIN III.

Although this is not a population-based study, the results represent a significant sample of the user population of the Brazilian public health system. Therefore, these estimates should be close to the actual values of a lowerincome population and could provide a reference for planning, assessment, and follow-up of cervical cancer screening activities. 


\section{Resumo}

O objetivo deste estudo foi estimar e analisar a prevalência das neoplasias intra-epiteliais cervicais (NIC) $e$ do carcinoma invasivo do colo uterino, com base no diagnóstico citológico. Foram incluídas $120.635 \mathrm{mu}$ lheres que realizaram o exame citológico, entre setembro de 1998 a março de 1999, nos serviços públicos de saúde da região de Campinas, Brasil. As prevalências por 100 mil mulheres foram: 354 para NIC I; 255 para NIC II; 141 para NIC III e 24 de carcinoma invasivo. À medida que a idade aumentou, as prevalências e razões de prevalência diminuíram para NIC I e NIC II, e aumentaram para NIC III até 50-54 anos, decrescendo após. A prevalência do carcinoma invasivo aumentou com a idade. O padrão da prevalência da NIC II é distinto do padrão da NIC III e semelhante ao da NIC I, o que não teria sido observado se fosse utilizado o Sistema de Bethesda.Ainda, a média da idade ao diagnóstico da NIC II foi cerca de dez anos menor que para NIC III. Portanto, um diagnóstico de lesão de alto grau, de acordo com o Sistema de Bethesda, em uma mulher jovem provavelmente seria NIC II e em uma mulher mais velha seria NIC III.

Neoplasia Intra-epitelial Cervical; Neoplasias Uterinas; Prevalência

\section{Contributors}

M. G. L. d'Ottaviano-Morelli and D. R. Terrabuio contributed to the data collection and analysis that originated the article and participated in constructing and organizing the database. M. G. L. d'Ottaviano-Morelli was also responsible for drafting the first version of the article. J. G. Cecatti and E. Z. Martinez prepared the study design, participated in the data analysis, and reviewed the article. L. Zeferino participated in all of the stages in the production of the article.

\section{Acknowledgments}

This study was supported by the São Paulo State Research Foundation (FAPESP 98/10388-4).

\section{References}

1. Robles SC, White F, Peruga A. Trends in cervical cancer mortality in the Americas. Bull Pan Am Health Organ 1996; 30:290-301.

2. Zeferino LC, Panetta K, Costa AM, Morelli MGLO, Pinotti JA. Programa de detecção do câncer de colo uterino de Campinas e região: 1968-1996. Revista Brasileira de Cancerologia 1999; 45:25-33.

3. Richart RM. The natural history of cervical intraepithelial neoplasia. Clin Obstet Gynecol 1967; 10:748-85.

4. Everitt BS. The analysis of contingence tables. 2nd Ed. London: Chapman \& Hall; 1992.

5. Goes Jr JS. Banco de dados para a prevenção e detecção do câncer: uma análise sobre nova base no Estado de São Paulo. São Paulo: Companhia de Processamento de Dados do Estado de São Paulo; 1988.

6. Ministério da Saúde. Programa Nacional de Controle do Câncer do Colo do Útero. 2a Fase de Intensificação, Relatório Preliminar http://www. inca.gov.br/prevencao/programas/viva_mulher/ documentos/relatorio2afase.pdf (acessed Jun/ 2002).

7. Kurman RJ, Solomon D. The Bethesda System for reporting cervical/vaginal cytologic diagnoses. New York: Springer-Verlag; 1994. 
8. Secretaria de Estado da Saúde do Paraná. Resultados de exames citopatológicos http://www. saude.pr.gov.br:2080/Cancer.nsf/Siscolo02?Open View.

9. Elias A, Linthorst G, Bekker B, Vooijs PG. The significance of endocervical cells in diagnosis of cervical epithelial changes. Acta Oncol 1983; 27:225-9.

10. Graaf YVD, Vous PG, Zielhuis GA. Population screening for cervical cancer in the Region Niejmegen: The Netherlands 1976-1985. Gynecol Oncol 1988; 30:388-97.

11. Chou P, Chen AV. Mass screening for cervical cancer in Taiwan from 1974 to 1984. Cancer 1989; 64:962-8.

12. Dabances A. Tasas estandardizadas de patología cervical preclínica obtenida por el programa de control precoz de cancer cervico-uterino, en la area metropolitana de Santiago. Rev Chil Obstet Ginecol 1989; 54:217-24.

13. Herrero R, Hildesheim A, Bratti C, Sherman ME, Hutchinson M, Morales J, et al. Population-based study of human papillomavirus infection and cervical neoplasia in rural Costa Rica. J Natl Cancer Inst 2000; 92:464-74.

14. Benard VB, Lee NC, Piper M, Richardson L. Racespecific results of Papanicolaou testing and rate of cervical neoplasia in the National Breast and Cervical Cancer Early Detection Program, 19911998 (United States). Cancer Causes Control 2001; 12:61-8.

15. Östör AG. Natural history of cervical intraepithelial neoplasia: a critical review. Int J Gynecol Pathol 1993; 12:186-92.
16. Syrjänen K, Syrjänen S. Natural history of cervical HPV and CIN. In: Syrjänen K, Syrjänen S, editors. Papillomavirus infections in human pathology. Chichester: John Wiley \& Sons; 1999. p. 143-66.

17. Adam E, Berkova Z, Daxnerova Z, Icenogle J, Reeves WC, Kaufman RH. Papillomavirus detection: demographic and behavioral characteristics influencing the identification of cervical disease. Am J Obstet Gynecol 2000; 182:257-64.

18. Londesborough P, Ho L, Terry G, Cuzick J, Wheeler C, Singer A. Human papillomavirus genotype as a predictor of persistence and development of high-grade lesions in women with minor cervical abnormalities. Int J Cancer 1996; 69:364-8.

19. Moscicki AB, Shiboski S, Broering J, Powell K, Clayton L, Jay N, et al. The natural history of human papillomavirus infection as measured by repeated DNA testing in adolescent and young women. J Pediatr 1998; 132: 277-84.

20. Zeferino LC, Bedone AJ, Faúndes A, Oyakawa N. Duração da neoplasia intra-epitelial e do carcinoma invasor do colo uterino: estudo epidemiológico. Revista Brasileira de Ginecologia e Obstetrícia 1998; 20:565-9.

21. Parkin DM. The epidemiological basis for evaluating screening policies. In: Franco E, Monsonego J, editors. New developments in cervical cancer screening. Cambridge: Blackwell Science; 1997. p. 51-69.

Submitted on 22/May/2002

Final version resubmitted on $05 /$ Jun $/ 2003$

Approved on $02 /$ Oct $/ 2003$ 